\title{
Genetic Variation in the Carbonic Anhydrase Isozymes of Macaque Monkeys. I. The Radioimmunosorbent Assay
}

\author{
Erik Magid, ${ }^{1,2}$ Joseph DeSimone, ${ }^{1,3}$ and Richard E. Tashian ${ }^{1}$
}

Received 21 Feb. 1972-Final 2 June 1972

A radioimmunosorbent technique is described which is capable of independently detecting both isozymes of carbonic anhydrase, $C A I$ and $C A I I$, in concentrations as low as $1 \mathrm{ng} / \mathrm{ml}$. The technique is used to quantitate the different electrophoretic variants of red cell CA I as well as levels of CA II in the pig-tailed macaque, Macaca nemestrina.

\section{INTRODUCTION}

The red cell carbonic anhydrase isozymes which have been designated CA I and CA II, or CA B and CA C, exhibit a marked degree of electrophoretic polymorphism in several species of monkeys belonging to the genus Macaca (Tashian et al., 1971). One species, Macaca nemestrina, the pig-tailed macaque, is of particular interest because four electrophoretic types of CA I (designated $\mathrm{CA} I \mathrm{Ia}, \mathrm{Ib}, \mathrm{Ic}$, and Id) are known to be controlled by alleles at the $C A I$ locus and two types (designated $\mathrm{CA} \mathrm{II}_{2}$ and $\mathrm{CA}$ IIb) are products of alleles at the $C A I I$ locus. In addition, a CA I deficiency phenotype was observed in which no CA I component could be detected by routine starch gel electrophoresis in approximately $30 \%$ of the individuals tested. However, with the use of a

Supported by U.S. Public Health Service research grant GM-15419.

${ }^{1}$ Department of Human Genetics, University of Michigan Medical School, Ann Arbor, Michigan.

${ }^{2}$ U.S. Public Health Service International Postdoctoral Fellow. Present address: Department of Clinical Chemistry, Bispebjerg Hospital, Bispebjerg Bakke 23, 2400 Copenhagen NV, Denmark.

${ }^{3}$ U.S. Public Health Service Predoctoral Trainee (GM-71-14). 
sensitive radioimmunoassay, $\mathrm{CA} I$ is found to be present in concentrations between 0.1 and $0.01 \%$ of the normal levels (Headings and Tashian, 1971). The deficiency condition is recessive and is inherited either as an allele of the $C A I$ locus or of some locus closely linked to it (Tashian et al., 1971). In these CA I deficient individuals, the levels of CA II are also found to be reduced, but to a much smaller degree, i.e., $30-50 \%$ of the normal levels (Headings and Tashian, 1971). Furthermore, it has been noted in our laboratory by inspection of a number of electrophoretic patterns that there seems to be a relationship between the quantity of CA I and its electrophoretic type. Thus, for example, the quantity of type CA Ia, as estimated from the proteinstained starch gels, appears to be lower than the quantity of type CA Ib, and this appears to be true whether the comparison is made within a sample from a heterozygous individual or between samples from individuals with different phenotypes ( $c f$. Fig. 1).

In attempting to elucidate the genetic mechanisms involved in the regulation of red cell carbonic anhydrase levels, it was decided to quantitate CA I and CA II in erythrocytes from a breeding colony of pig-tailed macaques. For this purpose, a procedure was developed which is based in part on the radioimmunoassay of carbonic anhydrase isozymes described by Headings and Tashian (1970) and partly on the radioimmunosorbent technique described by Wide (1969) for the quantitation of pituitary hormones.

\section{PROCEDURE}

\section{Material and Preparations}

The blood samples used in this study were obtained from a breeding colony of pig-tailed macaques at the University of Washington Regional Primate Center. Hemolysates were prepared from the red cells and subjected to vertical starch gel electrophoresis, using previously described techniques (Tashian, 1969). The concentration of hemoglobin in the hemolysates was determined spectrophotometrically as hemoglobincyanide (Kampen and Zijlstra, 1965). The zymogram patterns of some of the various electrophoretic types of CA I and their designations are shown in Fig. 1.

Human red cell CA I and CA II were isolated by means of column chromatography (Tanis et al., 1970), and highly specific rabbit antisera toward these isozymes were prepared as described by Headings and Tashian (1970). Their method for the iodination of the isozymes was followed unchanged except that $\mathrm{I}^{125}$ (half-life 56 days) and not $\mathrm{I}^{131}$ (half-life 8 days) was used as a label. The $\mathrm{I}^{125}$-labeled isozymes were used for a period not exceeding 6 weeks, and then a fresh preparation was substituted.

Sephadex G25 superfine (Pharmacia) was activated with cyanogen bromide (Eastman Organic Chemicals) and coupled to the rabbit immuno- 


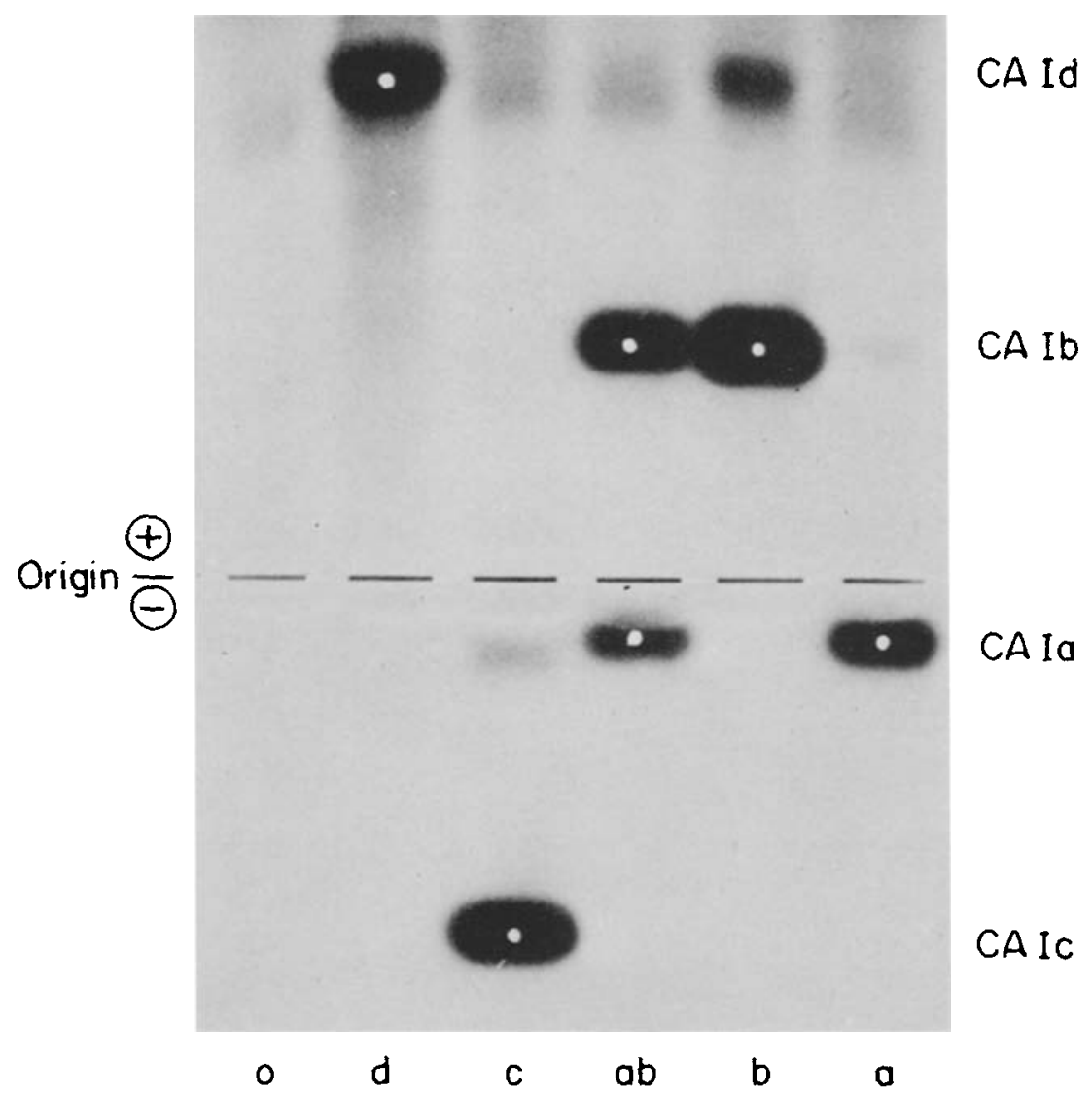

Fig. 1. Zymogram showing the electrophoretic phenotypes and the deficiency phenotype of CA I from $M$. nemestrina. Left to right: o (deficiency type), CA Id, CA Ic, CA Iab, $\mathrm{CA} \mathrm{Ib}$, and CA Ia. White dots indicate major components; all other bands represent minor components. For further details, see Tashian et al. (1971).

globulins obtained by sodium sulfate precipitation of the antisera as described by Wide (1969). The coupling procedure, and the subsequent washing of the immunosorbent, was performed at $4 \mathrm{C}$. The immunosorbent particles were stored in a concentration of $10 \mathrm{mg} / \mathrm{ml}$ at $-20 \mathrm{C}$ in the assay buffer, which was made up by combining $500 \mathrm{ml} 0.1 \mathrm{M}$ phosphate buffer, $p \mathrm{H} 7.5 ; 500 \mathrm{ml}$

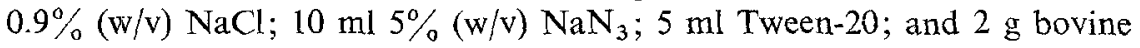
serum albumin (Sigma).

\section{The Radioimmunosorbent Assay}

The principle of both the radioimmunoassay and the radioimmunosorbent assay is a competition between radiolabeled and unlabeled antigen for a 
fixed number of antibody binding sites. One major advantage of the radioimmunosorbent technique is that the antibody is made insoluble by coupling to a polysaccharide in particle form whereby the isolation of the antigenantibody complex is greatly facilitated. Briefly, the radioimmunosorbent assay is performed by adding calibrated amounts of antibody coupled to Sephadex G25 (the immunosorbent) and labeled isozyme to test tubes containing aliquots of the samples. After incubation overnight, the immunosorbent is isolated by centrifugation, and the amount of bound label is determined in a gamma scintillation counter. The amount of radioactivity bound is in inverse proportion to the amount of isozyme originally present in the test tube.

The radioimmunosorbent assay was carried out as follows: To disposable polypropylene test tubes (12 by $75 \mathrm{~mm}$, No. 2005 Falcon Plastics, Oxnard, California) were added $1.0 \mathrm{ml}$ of assay buffer, $100 \mu \mathrm{l}$ of assay buffer containing labeled isozyme in an amount approximately equivalent to 75,000 counts $/ \mathrm{min}$, $100 \mu 1$ of either the unknown sample or a standard solution of purified isozyme appropriately diluted with the assay buffer, and finally $1.0 \mathrm{ml}$ of a suspension of the immunosorbent in the assay buffer. The amount of immunosorbent added to each test tube was $500 \mu \mathrm{g}$ in assays for CA I and $1000 \mu \mathrm{g}$ in assays for CA II. The test tubes were capped and secured in a test tube rack attached to a rotator (model $150 \mathrm{~V}$, Scientific Industries Inc.). The test

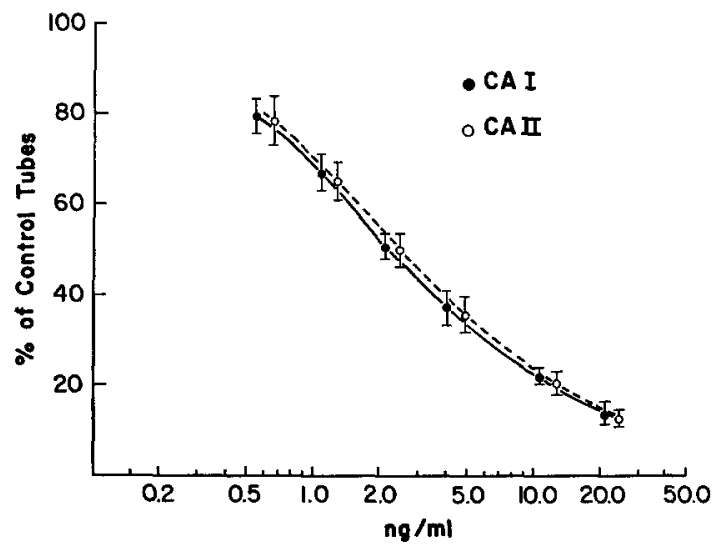

Fig. 2. Dose-response curves for carbonic anhydrase I and II in the radioimmunosorbent assay. Amount of bound label (ordinate) in percentage of the radioactivity bound in the absence of unlabeled enzyme is shown as a function of the concentration $(\mathrm{ng} / \mathrm{ml})$ of the isozyme in the test tubes. Results are mean values $\pm 2 \mathrm{sD}$ of data obtained over a 4 month period during which stock solutions of CA I $(479 \mu \mathrm{g} / \mathrm{ml})$ and CA II $(256 \mu \mathrm{g} / \mathrm{ml})$ were assayed eight and five times, respectively, in six different dilutions. 
tubes were rotated end over end at $12 \mathrm{rpm}$ for $18 \mathrm{hr}$ at $4 \mathrm{C}$. Subsequently, the test tubes were centrifuged, and the supernatant was discarded. The immunosorbent was washed three times in $2.5 \mathrm{ml}$ of a solution containing $0.9 \%(\mathrm{w} / \mathrm{v}) \mathrm{NaCl}$ and $0.5 \%(\mathrm{v} / \mathrm{v})$ Tween-20 ( $c f$. Wide, 1969). Finally, the test tubes were placed in a gamma scintillation counter for the determination of the amount of labeled isozyme bound to the immunosorbent.

In each series of determinations, the amount of label bound to the immunosorbent was determined in the presence of known amounts of the purified isozyme. A semilogarithmic plot of the radioactivity in these standard tubes as a function of the amount of isozyme added to the tubes yields a sigmoid curve (Fig. 2). The concentrations of the isozyme in the unknown samples were read from this curve. All determinations were performed in duplicate.

Using the amounts of labeled isozyme and immunosorbent stated above, approximately $10 \%$ of the label was bound to the immunosorbent in the absence of unlabeled competing enzyme during $18 \mathrm{hr}$ of incubation.

The preparations of the isozymes used as standards were purified from $M$. nemestrina red cells by column chromatography on DEAE-Sephadex (Tanis et al., 1970), and the concentrations of the isozymes in these purified preparations were determined spectrophotometrically ( $c f$. Magid, 1967).

\section{RESULTS AND DISCUSSION}

\section{The Standard Curve}

Preparations of the purified isozymes were stored as stock solutions at $4 \mathrm{C}$. In all series of determinations run during a 4 month period, these stock solutions were diluted and assayed in six different concentrations between 0.5 and $25.0 \mathrm{ng} / \mathrm{ml}$. Figure 2 shows the mean values of the radioactivity bound to the immunosorbent as a function of the isozyme concentration. The position of the standard curve is dependent on the amount of immunosorbent (i.e., antibody binding sites) and labeled isozyme added to the test system. Changes in these quantities occur from assay to assay and are in part responsible for the variation demonstrated in the figure. The results indicate that the standard curves were reproducible to a reasonable degree over a period of time during which different preparations of labeled isozyme and immunosorbent were used.

\section{Reproducibility}

Fresh hemolysates from a number of individuals were assayed for CA I, $\mathrm{CA}$ II, and hemoglobin. Subsequently, the hemolysates were stored at $4 \mathrm{C}$ for a period of 3-6 weeks, after which time the determinations were repeated. 
Table I. Repeated Determinations of Carbonic Anhydrase I and II in Hemolysates from $M$. nemestrina Performed with the Radioimmunosorbent Assay ${ }^{a}$

\begin{tabular}{|c|c|c|c|}
\hline \multicolumn{2}{|c|}{$\begin{array}{c}\text { CA I } \\
(\mu \mathrm{g} / \mathrm{mg} \mathrm{Hb})\end{array}$} & \multicolumn{2}{|c|}{$\underset{(\mu \mathrm{g} / \mathrm{mg} \mathrm{Hb})}{\text { CA II }}$} \\
\hline $\begin{array}{l}\text { First } \\
\text { determination } \\
\text { (a) }\end{array}$ & $\begin{array}{l}\text { Second } \\
\text { determination } \\
\text { (b) }\end{array}$ & $\begin{array}{l}\text { First } \\
\text { determination } \\
\text { (a) }\end{array}$ & $\begin{array}{c}\text { Second } \\
\text { determination } \\
\text { (b) }\end{array}$ \\
\hline 4.8 & 3.9 & 0.98 & 0.98 \\
\hline 6.3 & 5.2 & 1.25 & 1.58 \\
\hline 7.3 & 8.2 & 1.52 & 1.90 \\
\hline 8.5 & 7.9 & 1.52 & 1.56 \\
\hline 9.2 & 11.5 & 1.60 & 1.90 \\
\hline 9.2 & 9.6 & 1.65 & 1.68 \\
\hline 9.6 & 9.4 & 1.69 & 1.67 \\
\hline 10.2 & 12.7 & 1.77 & 1.73 \\
\hline 10.9 & 8.9 & 1.83 & 1.84 \\
\hline 10.9 & 12.5 & 1.96 & 2.20 \\
\hline 11.6 & 11.5 & 2.06 & 2.28 \\
\hline 12.2 & 12.9 & 2.07 & 2.33 \\
\hline 13.2 & 14.0 & 2.08 & 2.08 \\
\hline 16.4 & 15.8 & 2.35 & 2.42 \\
\hline \multirow{4}{*}{20.1} & 17.5 & 2.44 & 2.51 \\
\hline & & 2.48 & 2.51 \\
\hline & & 2.52 & 2.60 \\
\hline & & 2.53 & 2.49 \\
\hline${ }^{b} s=1.0$ & $s / \bar{X}=9.0 \%$ & $s=0.12$ & $s / \bar{X}=6.0 \%$ \\
\hline
\end{tabular}

${ }^{a}$ Samples were assayed twice within an interval of 3-6 weeks. For further details, see text.

${ }^{b} s=\sqrt{ }\left[\Sigma(a-b)^{2}\right] / 2 N$.

Table II. Red Cell Levels of CA I and CA II Associated with the Different CA I Phenotypes of $M$. nemestrina

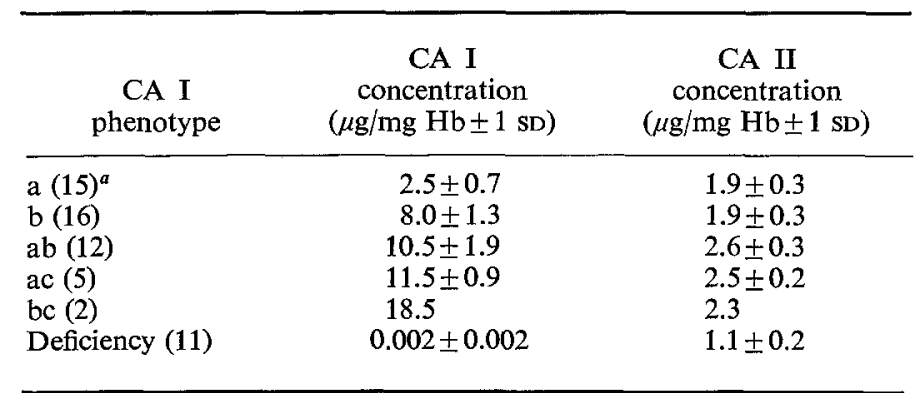

${ }^{a}$ Numbers of animals of each phenotype tested. 
The mean values of the duplicate determinations obtained in the first and the second series of determinations are shown in Table I. The results are given as $\mu \mathrm{g}$ enzyme $/ \mathrm{mg} \mathrm{Hb}$. The standard deviation of the difference $(s)$ was used to calculate the coefficient of variation $(s / \bar{X})$, which is an estimate of measurement error. The values were found to be $9 \%$ and $6 \%$ for CA I and CA II, respectively.

\section{Specificity}

Addition of CA I to a concentration of $21 \mathrm{ng} / \mathrm{ml}$ to the assay system for CA II did not significantly change the binding of labeled CA II to the immunosorbent. Similarly, CA II had no measurable effect on the binding of labeled CA I. It can also be demonstrated that the slopes of the dose-response curves are similar in the absence and presence of hemoglobin. These findings are in agreement with the results reported by Headings and Tashian (1970).

\section{Relationship Between CA I Phenotype and Red Cell Enzyme Levels}

The radioimmunosorbent assay as described above has been used to determine the levels of CA I and CA II in hemolysates from 54 pig-tailed macaques. From the results presented in Table II, it is apparent that a relationship exists between the CA I phenotype and the levels of that isozyme in the red cells. The data also show a nonrandom distribution of the values for CA II. These data will be analyzed and discussed in the following paper (DeSimone et al., 1973), in which additional information on the carbonic anhydrase isozyme system in the pig-tailed macaque is presented.

\section{ACKNOWLEDGMENTS}

We are especially grateful to Dr. Lloyd Dillingham and Dr. William Morton as well as the personnel of the University of Washington Regional Primate Center, both at Seattle and at Medical Lake, Washington, for their cooperation in securing the blood specimens used in this study. Success in the development of the procedures reported here was, in large measure, due to the dependable and painstaking assistance of Mrs. Ya-Shiou L. Yu.

\section{REFERENCES}

DeSimone, J., Magid, E., and Tashian, R. E. (1973). Genetic variation in the carbonic anhydrase isozymes of macaque monkeys. II. Inheritance of red cell carbonic anhydrase levels in different carbonic anhydrase I genotypes of the pig-tailed macaque, Macaca nemestrina. Biochem. Genet. 8:165.

Headings, V. E., and Tashian, R. E. (1970). A radioimmunoassay for quantifying carbonic anhydrase isozymes in crude lysates. Biochem. Genet. $4: 285$. 
Headings, V. E., and Tashian, R. E. (1971). Quantitative genetic variation in carbonic anhydrase isozymes from tissues of the pig-tailed macaque, Macaca nemestrina. Biochem. Genet. 5:333.

Kampen, E. J., and Zijlstra, W. G. (1965). Determination of hemoglobin and its derivatives. Advan. Clin. Chem. 8:141.

Magid, E. (1967). The activity of carbonic anhydrases B and C from human erythrocytes and the inhibition of the enzymes by copper. Scand. J. Haematol. 4:257.

Tanis, R. J., Tashian, R. E., and Yu, Y.-S. L. (1970). Properties of carbonic anhydrase isozymes isolated from porcine erythrocytes. J. Biol. Chem. 245:6003.

Tashian, R. E. (1969). The esterases and the carbonic anhydrases of human erythrocytes. In Yunis, J. J. (ed.), Biochemical Methods in Red Cell Genetics, Academic Press, New York, p. 307.

Tashian, R. E., Goodman, M., Headings, V. E., DeSimone, J., and Ward, R. H. (1971). Genetic variation and evolution in the red cell carbonic anhydrase isozymes of macaque monkeys. Biochem. Genet. 5:183.

Wide, L. (1969). Radioimmunoassays employing immunosorbents. Acta Endocrinol. 63:207 (suppl. 142). 